\title{
Assessment of Student Leaders' Skills Critical in Managing Student Affairs in Public Universities in Kenya
}

\author{
Murage Lucy Muthoni, Njoka Johannes Njagi, Gachahi Michael Wambugu \\ School of Education, Karatina University
}

Corresponding author: Murage Lucy Muthoni, E-mail: muragelucy77@gmail.com

\begin{tabular}{l} 
ARTICLE INFO \\
\hline Article history \\
Received: April 30, 2018 \\
Accepted: October 20, 2018 \\
Published: October 31, 2018 \\
Volume: $6 \quad$ Issue: 4 \\
\hline
\end{tabular}

Conflicts of interest: None Funding: None

\begin{abstract}
The need to prevent eruption of unrests among students in universities continues to exercise the minds of higher education managers and policy makers in the world. Innovative approaches in the management of higher education designed to preclude students' riots continue to face immense challenges and ineffectiveness in universities in Kenya. One of the widely adopted approaches is that of involving democratically elected student leaders in the management of students' affairs in universities in Kenya. Despite the involvement of student leaders in the management of students' affairs in public universities, students' protests and riots continue to characterize higher education in Kenya. Consequently, there is need to examine the leadership skills that student leaders are expected to possess in order to perform their functions effectively so as to avert upsurge of strikes. This study sought to assess the student leaders' skills that are critical in managing student affairs in selected public universities in Kenya. The study adopted the descriptive survey research design. Stratified random sampling was used to select student leaders from four public universities. The sample comprised 19 members of student governing councils, 50 class representatives and 79 clubs and society leaders, making a total of 142 respondents. Data was collected using questionnaires. Data was analysed using both descriptive and inferential statistics. The results revealed that $66.3 \%$ of student leaders had leadership competence to organize welfare activities to address students' concerns in their institutions while $33.7 \%$ lacked capability. Further, the study established that leadership skills significantly contributed to effective provision of student affairs services. It is concluded that institutions of higher learning have not fully empowered student leaders to effectively perform their leadership tasks. The study recommends that student leaders should be exposed to regular leadership trainings during their tenure designed to equip them with necessary leadership competencies which would promote their effectiveness in enhancing university stability, peace and mutually accepted governance.
\end{abstract}

Key words: Leadership Skills, Participative Leadership, Public Universities, Student Affairs, Student Leaders

\section{INTRODUCTION}

How to effectively integrate the diversity of student leadership in the university governance system continues to pose the greatest challenge to higher education managers, policy makers and stakeholders. Universities in the contemporary world have designed innovative approaches to university governance that involve effective participation and involvement of student leaders in management (Republic of Kenya, 2012a). However, despite harnessing the involvement of diverse students' leaders such as the students governing councils, class representatives, and clubs and societies leaders in university governance system, students' unrests and riots continue to characterize higher education in Kenya. Students continue to complain of unsatisfactory student affairs service delivery and unfulfilled welfare needs.
Leadership is the ability of an individual to influence and motivate others towards achievement of desired objectives (Spendlove, 2007). Okumbe (2007) contend that leadership is the capacity of a person to inspire others to progress in the direction of achieving organizational goals. Leadership is an incremental control that a man applies over another, past mechanical compliance with routine mandates. According to Kamugisha (2013), leadership is a noteworthy manner by which one changes the minds of followers and steer to achieve set objectives. Hence, student leaders should be able to influence both the university management and their counterparts in order to mutually come up with student affairs activities that satisfy the needs of the university and those of students' fraternity.

Leadership skills are characterized by a mixture of knowledge, gifts and traits that on the whole empower 
somebody to undertake a given assignment (Zenger and Folkman, 2002). Yukl (2006) relate leadership aptitudes with the capacity of a leader to set an example in acknowledging diverse values, beliefs and customs. According to Northouse (2013), trustworthiness, amiability, intellect and resilience are identifiable characteristics and attributes that add to an individual's capacity to be a leader. Smith (2007) avers that the ever-changing demographic today put less accentuation on managers of process, but pays more attention on leaders of individuals. She additionally affirms that leaders, who have been trained, accordingly mentor others and have more effect on management of student affairs by ethicalness of their soft skills.

The capacity to accept to lead when the circumstance calls for it, is a need for any individual who wants to draw upon their insight and hard skills in a place of influence while in university. Pascarella and Terenzini (2005) emphasize that students are capable of increasing their leadership skills during their college years. An example of factors that can anticipate different leadership results from the campus experience would include contribution in debate on societal issues and participating in activities of national importance. Companies desire to engage leaders not followers (Kristin, Gitile \& Wegulo, 2011). Hence, the best practice is to empower student leaders with leadership skills upon assumption of their office through structured capacity building techniques.

\section{Statement of the Problem}

The management of the affairs of the students in public universities continues to be a major concern of the education stakeholders in Kenya. This is because, universities in Kenya are characterized by regular students' unrests and riots occasioned by perceived unresponsiveness by university management to the needs and requirements of students. Students are known to lay a lot of blame on university management for the eruption of protests that result in great loss of valuable academic time, destruction of resources and long closures of universities. The provision of quality student affairs services depends on student leadership and competency to address students' concerns. It is against this background that the researchers sought to assess the student leaders' skills that are critical in managing student affairs in selected public universities in Kenya.

\section{Purpose of the Study}

The purpose of the study was to assess the leadership skills that students' leaders should possess in order to effectively provide satisfactory student affairs services to students.

\section{Objectives of the Study}

The study was based on the following objectives, which were to;

i. Evaluate the leadership skills that student leaders require to possess in order to manage student affairs in public universities in Kenya ii. Analyse how student leadership is enhanced in public universities in Kenya.

\section{Null Hypothesis}

The study tested the following null hypothesis;

$\mathrm{H}_{\mathrm{o}}$ : There was no significant relationship between leadership skills and effective management of student affairs.

\section{LITERATURE REVIEW}

This section highlights the significance of leadership skills to student leaders. How leadership capacity can be enhanced is also outlined. The above aspects are important for leadership development.

\section{Significance of Leadership Skills}

From time immemorial to present day times, leadership has been fundamental in all aspects of human undertakings, including educational institutions. Graduates produced in universities are expected to fill leadership positions in the job market that include companies' executives, communication specialists and trainers in various fields. Universities are confronted with demanding but recompensing task of developing efficient leaders for the $21^{\text {st }}$ century management roles (Sacks, 2009). Student leaders are therefore, expected to demonstrate leadership competencies that have a stronger influence on the students and beyond.

Students' idea of being an exemplary leader at any level and how to develop one's leadership abilities is has not been given much attention in institutions of higher learning (Republic of Kenya, 2010). The Kenyan media tend to centre its broadcasting for the most part on political leadership hence associating leadership with places of riches, expert, influence and popularity. This befuddles young people to the degree that they lack focus of what makes an individual a leader within one's range of prominence (Kristin et al., 2011). In most scenarios, adults do not know how to engage the youth in significant leadership openings though they may offer apparently positive comments like, "young people are the leaders of tomorrow". This keeps on inferring that leadership is something that elders do and not youth (Nelson, 2010). Leadership engagements should start at early age and in all areas so as to gain experience in the process.

The needs of our learners and of the societies that our universities serve are constantly transmuting. Hence, there is need to re-train the current student leaders and to systematically prepare them for new emerging roles in the changing world. Leadership skills are fundamental components in positioning student leaders towards making considerate choices around their union's objectives and suitably allocate resources to accomplish those objectives (Zenger \& Folkman, 2002). Student leaders are expected to demonstrate appropriate management competencies in order to positively influence their colleagues. Problem solving skills are necessary in leadership positions.

Moreover, student leaders are confronted with various unforeseen difficulties in their line of duty and get almost 
no guide in conquering them (Republic of Kenya, 2014). They should have the capacity to tackle issues in innovative approach and to determine answers for students' concerns utilizing guided principles (Kristin et al., 2011). Student leaders who are acquainted with learned procedures and are not flexible will battle to deal with unpredicted hitches in leadership. Student leaders can enhance critical thinking capacities by taking interest in exercises that utilize experiential knowledge as opposed to rote learning. They ought to likewise attempt new ventures that place them in challenging environments such as team building, organizing workshops and seminars for students.

Leadership gap may create obstacles to stability and security practicability of university and ought to be addressed as soon as possible (Republic of Kenya, 2014). University management should embrace valiant measures to address leadership gaps by integrating leadership skills development in all aspects of student's campus life. University administration also needs reform by moving from institutionalized and command driven types of administration to more decentralized and participatory leadership (Nyaigotti, 2001). Universities should soar above the occasional student protests that disrupt learning. They should design innovative programmes that promote the competency required to produce influential student leadership, in a turbulent setting where transformation is unavoidable (Kristin et al., 2011). Effective provision of student services requires student leaders who are well equipped with knowledge and skills relevant to services provided.

\section{Leadership Capacity Enhancement}

The prominence of reinforcing education's contribution to the accomplishment of equity and responsible citizenship from local to international levels need to be emphasized (UNESCO, 2015a). Education is a common good that must be provided under the control of government though neoliberalism has underrated its conventional notion (UNESCO, 2015b). Rao and Georgas (2015) in their study argue that neoliberalism structural adjustment programmes have brought about decentralization and cost-sharing in education in the developing countries. World Bank and IMF have pushed states and governments to buy into the neoliberal idea that public funding in education must be reduced. This has led to introduction of new features to African higher education including withdrawal of education subsidies, along with the privatisation of students' support services such as accommodation and catering (Wangenge-Ouma, 2012). The reduced spending on education has lowered the standards of living leading to constant conflict between students and university management as students demand for provision of better services.

However, neoliberalism has so far not been proven to be successful at bringing about efficiency or equity from devolved cost-sharing of education in developing nations (Rao \& Georgas, 2015). Edwards (2011) asserts that devolution policies are usually established and applied without involvement of key downward stakeholders. Such policies end up being rejected at the implementation level and therefore are not effective. Although, the scarcity of resources is real, some of issues like management of student affairs are matters of organization culture. Management of student affairs requires rational student leadership action more than financial resources.

The significance of augmenting leadership capacity among student leaders cannot be underestimated. The teaching and learning environment provide a fertile ground for inculcating these invaluable abilities. For successful management of student affairs, more opportunities need to be opened up to students to enrich their leadership capability through leadership related activities. Some of the methods of improving leadership abilities include training, mentorship, assigning leadership roles and developing a reward system to acknowledge students' efforts.

Training is an organized activity that imparts knowledge and skills specially packaged to promote student leaders' performance. It is an exercise that inculcates student leaders with the skills necessary to undertake their role effectively. A university exists to prepare students intellectually as well as to transform them holistically (Kristin et al., 2011). Real learning materialises when student leaders are presented with quality guideline supported by sound training condition. The scholarly world is a preparation ground for future experts of the society and the nation. It is imperative that an institution should equip student leaders with an enlightening college life. This is by presenting them to different projects, exercises intended to investigate, enrich and expand their maximum capacity for self-awareness and social obligation. Another approach is to provide participation training at the foundation level, giving particular skills to student leaders.

Kenyan students get insignificant mentoring on leadership as the university curriculum lay less emphasize on leadership development (Republic of Kenya, 2012b). Indeed, the knowledge, skills and attitudes that would nurture leadership improvement may not necessarily be tested in a formal examination and therefore not taken seriously by students. However, these students are relied upon to take up leadership roles in their institutions and society as they enter the labour force (Kristin et al., 2011). Universities, the makers of leaders, have an indispensable mandate to play in modelling self-propelled citizens, empowered as change specialists who can be relied upon to emphatically reform their institutions and the community. Kenny, Aluede and McEachern (2009) assert that students in higher institutions of learning have numerous challenges and therefore students' counsellors and trainers ought to consistently evaluate students' concerns and provide accessible information and services that would be useful in easing their concerns. Accordingly, workshops on negotiation skills, administration of student crises, time and stress management, career choices and development could be offered to student leaders as an aide to their scholastic work.

Education does not cultivate critical thinking and investigative aptitudes required for development. Institutions have not adjusted to students' non-scholastic needs. Educators tend to focus on examination oriented content thus the educational programmes do not provide holistic development 
of students. There is need for review of university curriculum to include non-examinable aspects in social and spiritual development of students. Kristin et al. (2011) on nurturing student leadership skills affirm that students in our Kenyan universities are hardly sensitized on challenges ahead. Students for the most part turn out from colleges with strong scholarly foundation, yet with little leadership skills.

Lizzio and Wilson (2009) contend that specific aptitudes and demeanours are prerequisite for satisfying the obligation of exemplification. That is the reason it would be helpful if universities were to consistently design systems which enhance talents. This could be realizable by student leaders receiving recognition for their contributions and achievements, sponsoring peer counselling mechanisms and utilization of the instructional interactions given in a classroom environment. A reward system should be developed where student leaders who are performing exceptionally well in their areas of influence are appreciated.

The primary means to successfully lead others is the ability to overcome personal problems by exploring ways to enhance the abilities for self-management and ethical decision-making. When leading others, you require the understanding of the organization's hierarchical alignment, team dynamics, principles and methods of governance, designation of duties and obligations of stakeholders (Zenger \& Folkman, 2009). Student leaders given the fervent commitment of being the voice of their peer must endeavour to hone their leadership capacities by all means. This is in order to achieve positive transformations and become mentors whom different students can imitate as agents of change. Alongside the positive attributes of change agents is genuineness, accountability, religious, scholarly, inventive and aggressive.

Student leaders have a major responsibility of helping their colleagues to achieve peculiarity that could brand their university and turn it into a model in the worldwide level (Republic of Kenya, 2012a). They ought to likewise be knowledgeable in different fields in order to have the capacity to handle distinctive talents amongst students. Desirable leadership attributes incorporate the capacity to designate, motivate and communicate well (Yukl, 2006). A student leader should have strong leadership, organizational and public speaking skills. He/she should be deadline-oriented, able to build consensus and help bring the diverse student body together as a community through programmed and non-programmed events. Collaboration enhances leadership skills. It of essence for student leader to work productively in gatherings, acknowledge feedback and admit mistakes when working with others. Student leaders who succeed just when working alone will battle in work environment and beyond, as the larger part of professions require cooperation. Student leaders can build up the skills important to viably work with others in several ways, including sorting out and taking part in community outreach, team-based projects and co-curricular activities that promote integration among students.

Protests over unsatisfactory provision of student services as well as constant closure of public universities have become a regular phenomenon in Kenya (Ministry of Education Science and Technology, 2014). Students continually com- plain of poor conditions of residential and catering facilities, increased fees, inadequate representation in the senate and poor communication with university management (Republic of Kenya, 2014). The key to unlock these challenges is by harnessing student leaders, enhance their leadership capacity to enable them provide effective student services and position them at the centre of the management of student affairs. Such leaders may assist university management by improving staff and student relationships, reducing indiscipline cases and improving performance in both academic and co-curricular programmes (UNICEF, 2013). Eventually, they provide leadership that transform institutions from crisis to success.

\section{METHODS}

The study adopted the descriptive survey research design (Creswell, 2003). Stratified random sampling was used to select student leaders from (1) one established public university in terms of infrastructure, development and the general appearance and (3) three recently instituted, less established public universities in Kenya. The research used 30\% of the target population to get the sample of 19 members of student governing councils, 50 class representatives and 73 clubs and societies' leaders, making a total of 142 student leaders. Data was collected from primary sources using structured questionnaire (Mugenda and Mugenda, 2003). The questionnaire contained both open ended and closed questions. Open ended questions were used to collect qualitative data while closed questions in the questionnaire were used to collect quantitative data. Data was analysed using both descriptive and inferential statistics. Data was presented using narration and frequency tables.

\section{RESULTS AND DISCUSSION}

The number of questionnaire administered were 142 while those that were returned were 138; that is, a response rate of $97.2 \%$. Results and discussions were based on the stated objectives and hypothesis of the study.

a) The study sought to analyse the leadership skills that student leaders should possess in order to effectively manage students' affairs in public universities in Kenya. The findings of the data analysis are indicated in Table 1.

Data analysis was conducted in regard to leadership skills expected of student leaders' instrumental in enabling them to effectively execute their functions. Results of data analysis were reported in accordance with the items listed in the Likert scale analysed in Table 1 and presented as follows;

$i$. Student leaders recognize one's weaknesses and seek training to enhance leadership skills

The study sought to find out whether student leaders recognize one's weaknesses and seek training to enhance their leadership skills. The results revealed that $67.4 \%$ of the respondents strongly disagreed/disagreed, $28.3 \%$ strongly agreed/agreed and $4.3 \%$ were undecided. This implies that student leaders' inability to identify their weaknesses will result in inadequate leadership skills. Inadequate leadership 
Table 1. Results of analysis of leadership skills

\begin{tabular}{|c|c|c|c|c|c|c|c|c|c|c|}
\hline \multicolumn{2}{|c|}{ Skills } & \multirow{2}{*}{$\begin{array}{c}\text { Frequency } \\
\text { \& \% } \\
\mathrm{f}\end{array}$} & \multirow{2}{*}{$\begin{array}{c}\text { Strongly } \\
\text { disagree }\end{array}$} & \multirow{2}{*}{$\begin{array}{c}\text { Disagree } \\
24\end{array}$} & \multirow{2}{*}{$\begin{array}{c}\text { Undecided } \\
6\end{array}$} & \multirow{2}{*}{$\begin{array}{c}\text { Agree } \\
19\end{array}$} & \multirow{2}{*}{$\begin{array}{c}\begin{array}{c}\text { Strongly } \\
\text { agree }\end{array} \\
20\end{array}$} & \multirow[t]{2}{*}{ NR } & \multirow{2}{*}{$\begin{array}{c}\mathbf{M} \\
3.42\end{array}$} & \multirow{2}{*}{$\begin{array}{l}\text { SD } \\
1.31\end{array}$} \\
\hline 1 & Student leaders recognize one's & & & & & & & & & \\
\hline & $\begin{array}{l}\text { weaknesses and seek for training to } \\
\text { enhance leadership skills }\end{array}$ & $\%$ & 50 & 17.4 & 4.3 & 13.8 & 14.5 & & & \\
\hline \multirow[t]{2}{*}{2} & \multirow{2}{*}{$\begin{array}{l}\text { Student leaders build mutual relations } \\
\text { with comrades over divergence views }\end{array}$} & $\mathrm{f}$ & 11 & 8 & 16 & 59 & 41 & 3 & 3.82 & 1.17 \\
\hline & & $\%$ & 8 & 5.8 & 11.5 & 42.8 & 29.7 & 2.2 & & \\
\hline \multirow[t]{2}{*}{3} & \multirow{2}{*}{$\begin{array}{l}\text { Student leaders promote positive } \\
\text { communication with university } \\
\text { administration and students }\end{array}$} & $\mathrm{f}$ & 63 & 42 & 11 & 11 & 11 & & 3.82 & 1.18 \\
\hline & & $\%$ & 45.6 & 30.4 & 8 & 8 & 8 & & & \\
\hline \multirow[t]{2}{*}{4} & \multirow{2}{*}{$\begin{array}{l}\text { Student leaders lead meetings using } \\
\text { agenda management tactics. }\end{array}$} & $\mathrm{f}$ & 14 & 27 & 19 & 36 & 42 & & 3.47 & 1.36 \\
\hline & & $\%$ & 10.1 & 19.6 & 13.8 & 26.1 & 30.4 & & & \\
\hline \multirow[t]{2}{*}{5} & \multirow{2}{*}{$\begin{array}{l}\text { Student leaders display confidence in } \\
\text { the ability of an individual to design } \\
\text { strategies to reform their institution. }\end{array}$} & $\mathrm{f}$ & 34 & 9 & 8 & 52 & 35 & & 3.69 & 1.11 \\
\hline & & $\%$ & 24.6 & 6.5 & 5.8 & 37.7 & 25.4 & & & \\
\hline
\end{tabular}

NR (No Response), M (Mean), SD (Standard Deviation)

skills will limit their capacity to lead. According to Kristin et al. (2011), Kenyan students receive minimal mentorship on leadership. Nevertheless, these students are looked upon to provide leadership in their society later in their life. There is therefore need to regularly sensitize students on the principles and processes of leadership.

ii. Building supportive relationships with colleagues

The research investigated whether student leaders build mutual relations with students over divergent views in the universities. With regard to the above statement, the results revealed that $72.5 \%$ of the respondents strongly agreed/ agreed while $13.8 \%$ strongly disagreed/disagreed, $11.6 \%$ were undecided and $2.2 \%$ did not respond. This empirical evidence demonstrates a positive aspect of student leadership. UNICEF (2013) support that student leaders assist in management by improving staff and student relationships, reducing indiscipline cases and improving performance in co-curricular programmes.

iii. Promotion of positive communication

In relation to communication, $76.1 \%$ of the student leaders strongly disagreed/disagreed that they promote positive communication between university administration and students, $16 \%$ strongly agreed/agreed and $8 \%$ were undecided. This implies that there is a challenge of communication within the university fraternity. Standa (2007) pointed out that effective communication is crucial for implementation of university policies and programmes. Ineffective communication may affect the provision of student services which rely mainly on acceptance of management decisions by the students.

iv. Effective management of meetings

The study sought to establish whether student leaders lead meetings through the use of agenda management strategies. The result showed that $56.5 \%$ of respondents strongly agreed/ agreed, $29.7 \%$ strongly disagreed/disagreed and $13.8 \%$ were undecided. This demonstrates a positive aspect of student leaders' ability to manage and lead meetings which is an element of good communication strategies.

\section{v. Confidence of leaders to design strategies}

The study evaluated whether student leaders exhibited confidence in designing strategies to transform their institution. The results indicated that $63.1 \%$ of the student leaders strongly agreed/agreed, $30.1 \%$ strongly disagreed/disagreed and $5.8 \%$ were undecided. In order to lead others successfully, one requires the capacity to lead oneself by exploring ways to understand and enhance the abilities for self-management and ethical decision-making. When leading others, you require the understanding of the organizational vision, group dynamics, delegation of duties and answerability. Sarua (2009) concurs that establishment of student governance in higher education is to assist them build confidence and counter the emerging challenges within the student body.

b) The second objective sought to analyse how student leadership is enhanced in public universities in Kenya. The findings of the data analysis are indicated in Table 2 .

Data analysis was conducted in regard to leadership enhancement techniques that student leaders exposed their fellow students in while promoting their welfare. Results of data analysis were reported in accordance with the items listed in the Likert scale analysed in Table 2 and presented as follows; $i$. Encouragement to engage in teamwork

The study examined whether student leaders encouraged students to engage in team building activities. With regard to teamwork, the findings revealed that $73.9 \%$ of respondents strongly agreed/agreed while $19.5 \%$ strongly disagreed/disagreed and $6.5 \%$ were undecided. This demonstrates a positive aspect of students' ability to build teamwork. According to Kouzes and Posner (2005), the ability of student leaders to inspire other students to engage in activities to transform their organization is the responsibility of student leaders.

ii. Development of practical and realistic welfare programmmes

The research sought to determine if student leaders developed practical and realistic welfare programmes for students. The result indicated that $55.8 \%$ of respondents 
strongly disagreed/disagreed while $30.5 \%$ strongly agreed/ agreed, $11.6 \%$ were undecided and $2.2 \%$ did not respond. The results portray a weak aspect of student leaders. Inability to initiate projects that promote student welfare point to a gap in student leadership that must be filled.

iii. Utilization of students'suggestions

The study evaluated whether student leaders utilized suggestions from students to improve performance of the university. The result revealed that $65.2 \%$ of respondents strongly disagreed/disagreed while $21.8 \%$ strongly agreed/agreed, $11.6 \%$ were undecided and $1.4 \%$ did not respond. Student leaders need to enhance positive attitude towards students' proposals and establish a cordial working relationship with them. Attention should be focused on provision of space and time to consult with students. Regarding the daily duties, there should be a reasonable solicitation of students' perception regarding the provision of student services.

iv. Student leaders display integrity in all areas

The study sought to find out if student leaders displayed integrity in all areas of human relationships. Results indicated that $66.7 \%$ of the respondents strongly disagreed/disagreed while $23.9 \%$ strongly agreed/agreed, $7.2 \%$ were undecided and $2.2 \%$ did not respond. According to Zenger and Folkman (2002), some competencies are associated with leadership effectiveness in an organization. These include truthfulness, dependability, inventiveness and self-discipline.

v. Demonstration of flexibility

The study assessed whether student leaders exhibit flexibility by adjusting to different circumstances. Results showed that $65.2 \%$ strongly agreed/agreed while $18.1 \%$ strongly disagreed/disagreed and $16.7 \%$ were undecided. This implies that most of student leaders have the ability to adapt to dif- ferent situations within the university. Universities exist in a changing environment; campus life is dynamic and students needs and interests keep on changing. This is in line with Kamugisha (2013) who affirms that as the internal and external environment changes, leadership tactics need also to be revolutionized to enable student leaders to design new strategies that assist students to adapt to the changing environment. c) Hypothesis

It was stated that there was no significant relationship between leadership skills and effective management of student affairs. The findings from hypothesis testing showed that there was a significant relationship between leadership skills and effective management of student affairs. The result shows the variation of variables used in the analysis. $\mathrm{R}$-square which is the coefficient of determinant indicates how much variation is taking place in effective management of student affairs and leadership skills (Table 3 ).

The relationship between the leadership skills and effective management of student affairs is strong and statistically significant at 0.05 levels of significant with a Pearson correlation coefficient of 0.626. Therefore, the leadership skills and effective management of student affairs are positively related. The null hypothesis which states that, there is no significant relationship between leadership skills of student leaders and effective management of student affairs is rejected and the alternative accepted.

\section{CONCLUSION}

The results revealed a fair level of leadership skills among respondents as most of student leaders exhibited leadership competence to organize welfare activities to transform their institutions. Leadership skills' training therefore improves

Table 2. Results of analysis of leadership enhancement

\begin{tabular}{|c|c|c|c|c|c|c|c|c|c|c|}
\hline \multicolumn{2}{|c|}{ Skills } & \multirow{2}{*}{$\begin{array}{l}\text { Frequency } \\
\& \% \\
\mathrm{f}\end{array}$} & \multirow{2}{*}{$\begin{array}{c}\begin{array}{r}\text { Strongly } \\
\text { disagree }\end{array} \\
9\end{array}$} & \multirow{2}{*}{$\begin{array}{c}\text { Disagree } \\
18\end{array}$} & \multirow{2}{*}{$\begin{array}{c}\text { Undecided } \\
9\end{array}$} & \multirow{2}{*}{$\begin{array}{c}\text { Agree } \\
68\end{array}$} & \multirow{2}{*}{$\begin{array}{c}\begin{array}{c}\text { Strongly } \\
\text { agree }\end{array} \\
34\end{array}$} & \multirow[t]{2}{*}{ NR } & \multirow{2}{*}{\begin{tabular}{|c|}
$\mathbf{M}$ \\
3.72
\end{tabular}} & \multirow{2}{*}{$\begin{array}{l}\text { SD } \\
1.16\end{array}$} \\
\hline 1 & Student leaders inspire students & & & & & & & & & \\
\hline & $\begin{array}{l}\text { to take part in team building } \\
\text { exercises. }\end{array}$ & $\%$ & 6.5 & 13 & 6.5 & 49 & 25 & & & \\
\hline \multirow[t]{2}{*}{2} & \multirow{2}{*}{$\begin{array}{l}\text { Student leaders develop practical } \\
\text { and realistic welfare programs }\end{array}$} & $\mathrm{f}$ & 57 & 20 & 16 & 11 & 31 & 3 & 3.32 & 1.21 \\
\hline & & $\%$ & 41.3 & 14.4 & 11.6 & 8 & 22.5 & 2.2 & & \\
\hline \multirow[t]{2}{*}{3} & \multirow{2}{*}{$\begin{array}{l}\text { Student leaders use } \\
\text { recommendations from students to } \\
\text { enhance performance }\end{array}$} & $\mathrm{f}$ & 60 & 30 & 16 & 15 & 15 & 2 & 3.55 & 1.25 \\
\hline & & $\%$ & 43.5 & 21.7 & 11.6 & 10.9 & 10.9 & 1.4 & & \\
\hline \multirow[t]{2}{*}{4} & \multirow{2}{*}{$\begin{array}{l}\text { Student leaders demonstrate } \\
\text { honesty in every aspect of human } \\
\text { relations }\end{array}$} & $\mathrm{f}$ & 60 & 32 & 10 & 11 & 22 & 3 & 3.59 & 1.24 \\
\hline & & $\%$ & 43.5 & 23.2 & 7.2 & 8 & 15.9 & 2.2 & & \\
\hline \multirow[t]{2}{*}{5} & \multirow{2}{*}{$\begin{array}{l}\text { Student leaders show flexibility by } \\
\text { adapting to different situations }\end{array}$} & $\mathrm{f}$ & 14 & 11 & 23 & 54 & 36 & & 3.63 & 1.23 \\
\hline & & $\%$ & 10.1 & 8 & 16.7 & 39.1 & 26.1 & & & \\
\hline
\end{tabular}

Table 3. Results of relationship between leadership skills and effective management of student affairs

\begin{tabular}{lccccccccc}
\hline Model & R & R square & $\begin{array}{c}\text { Adjusted } \\
\text { R square }\end{array}$ & $\begin{array}{c}\text { Standard error } \\
\text { of the estimate }\end{array}$ & \multicolumn{4}{c}{ Change statistics } \\
\cline { 6 - 10 } & & & & $\begin{array}{c}\text { R square } \\
\text { change }\end{array}$ & F change & df1 & df2 & $\begin{array}{c}\text { Sig. } \\
\text { F change }\end{array}$ \\
\hline 1 & $0.626^{\mathrm{a}}$ & 0.392 & 0.388 & 0.139163 & 0.392 & 87.728 & 1 & 136 & 0.000 \\
\hline
\end{tabular}

a. Predictors: (Constant), Leadership skills required 
the effectiveness of student leaders. A significant number of student leaders showed insufficient leadership capabilities. Inadequate leadership skills results imply that some of student leaders are unable to discharge their duties effectively which may have translated to ineffectiveness in some areas like developing realistic welfare programmes and promoting effective communication between students and university administration. The study concluded that in institutions of higher learning, student leaders are not fully empowered to effectively perform their leadership tasks.

The study recommends that there is need to empower student leaders with abilities and skills through leadership inductions and trainings. In order to have structured and coordinated leadership inductions and trainings across all the universities, there is need to develop a student leaders' training manual that addresses all fundamental abilities and competencies required for effective leadership.

\section{REFERENCES}

Creswell, J.W. (2003). Research Design: Qualitative, Quantitative and Mixed Methods approaches: ( $2^{\text {nd }}$ ed.). Thousand Oaks, CA: Sage.

Edwards, R. M. (2011). Disconnect and capture of education decentralisation reforms in Nepal: implications for community involvement in schooling, Globalisation, Societies and Education. Routledge.

Kamugisha, S. (2013). The Effects of Change Management in an Organization: a case study of National University of Rwanda. (Published $\mathrm{PhD}$ thesis).

Kenny, M. C., Aluede, O. \& McEachern, A. G. (2009). A Comparison of Counselling Students Needs in the United States and Nigeria. Australian Journal of Guidance and Counselling, 19(1), $41-45$.

Kouzes J.M. \& Posner B.Z. (2005). Student Leadership Practices Inventory (SLPI). San Francisco, CA: Jossey Bass.

K'Okul, F. (2010). 'Perception of Students on the Status of Guidance and Counselling Selected universities in Kenya for Minimizing Student Riots', (Unpublished PhD thesis), Kenyatta University.

Kristin B.N., Gitile J.N. \& Wegulo N.F. (2011). Nurturing Student Leadership Skills. International Journal of Business and Public Management. 2(2), 39-46.

UNICEF (2013). Student Leadership Programme: How Far Are $W e$ ? Reflections from Student Leaders on the Implementation of Student Councils in Secondary Schools in Kenya.

Lizzio, A. \& Wilson, K. (2009). Student Participation in University Governance: The Role Studies in Higher Education. 34, 69-84.

Ministry of Education, Science and Technology. (2014). Report to Parliament by the Minister for Education; On Unrest in Education Institutions. Nairobi.

Mugenda, O.M. \& Mugenda, A.G. (2003). Research Methods. Nairobi: Acts Press.

Nelson, A. (2010). Stepping in early to grow great leaders. Leadership in Action, 29(6), 20-24. Retrieved from http://www.ncbi.nlm.nih.gov/pubmed/15605569.

Northouse, P. G. (2013). Leadership defined. Leadership: Theory and Practice, 6, 2-6.
Nyaigotti-Chacha, C. (2001). Issues of Leadership and Management of Innovations, Paper Presented at the Ford Foundation Conference on 'Innovations on African Higher Education'. Nairobi.

Okumbe, J.A. (2007). Educational Management Theory and Practice. Nairobi: University Press.

Pascarella, E.T. \& Terenzini, P.T. (2005). How College Affects Students: A Third Decade of Research. San Francisco: Jossey Bass.

Rao, A. S. \& Georgas, T. (2015). 'A look at Neoliberal Forces, Decentralisation and the Cost-Sharing of Education'. Global Journal of Interdisciplinary Social Sciences, 4(6), 45-46.

Republic of Kenya (2014). Report of the Vice Chancellors Committee on Causes of Disturbances/Riots in Public Universities. Nairobi: Government Printer

Republic of Kenya. (2012a). Universities Act 2012. In Kenya Gazette Supplement No. 192 (Act No.42). Nairobi: Kenya Government Printers.

Republic of Kenya (2012b). Kenya Vision 2030: A Globally Competitive and Prosperous Kenya.

Republic of Kenya. (2010). Commission for higher education annual report and database. Nairobi: Ministry of Higher Education, Research, Science and Technology.

Sacks, R. (2009). Natural born leaders: An exploration of leadership development in children and adolescents. Ottawa, Canada: Heritage.

Sarua. (2009). Leadership Challenges for Higher Education in Southern Africa: Southern Africa Regional Universities Association Leadership Dialogue Series, 1(1).

Sifuna, D.N. (2010). Some Reflections on the Expansion and Quality of Higher Education in Public Universities in Kenya, Research in Post-Compulsory Education, 15(4).

Smith, B. (2007). Coaching Emotional Intelligence: The Business Case for Human Capital. International Journal of Coaching in Organizations, 5 (3), 8-20.

Spendlove, M. (2007). Competencies for Effective Leadership in Higher Education, International Journal of Educational Management, 21 (5).

Standa, E. (2007). Institutional Autonomy and Academic Freedom. The Uganda Higher Education Review. Journal of Higher Council for Education. 4(1), 17-20.

UNESCO. (2015a). Education 2030 Incheon Declaration and Framework for Action. Towards inclusive and equitable quality education and lifelong learning for all. Paris, UNESCO.

UNESCO. (2015b). Rethinking Education: Towards a global common good? Paris, UNESCO.

Wangenge-Ouma, G. (2012).Tuition fees and the challenge of making higher education a popular commodity in South Africa. Higher Education, 64(6), 831-844.

Yukl, G. (2006). Leadership in Organizations. (6 ${ }^{\text {th }}$ ed.). Upper Saddle River, NJ: Prentice Hall.

Zenger, J. H., \& Folkman, J.R. (2002). The Extraordinary Leader. New York: McGraw Hill.

Zenger, J. H. \& Folkman J. R. (2009). The Extra-Ordinary Leader: Turning Good Managers into Great Leaders. New York: McGraw-Hill. 